\title{
Analisis Dampak Kebijakan Moneter terhadap Pertumbuhan Ekonomi di Indonesia
}

\author{
Hari Winarto*, Adi Poernomo, Agus Prabawa \\ Fakultas Ekonomika dan Bisnis Universitas Wijayakusuma Purwokerto \\ *Correspondence email: hari.unwiku@gmail.com
}

\begin{abstract}
The circuit of government monetary policy which is still uncertain in influencing economic growth is an interesting phenomenon to be examined, especially because it occurs in the era of globalization where monetary traffic is very rapid, the situation is the main problem in this study. Therefore, this study aims to determine the impact of monetary policy on economic growth in Indonesia using quantitative analysis methods. The type of data used is secondary data in the form of Time Series originating from the Central Statistics Agency, Bank Indonesia, and the Ministry of Trade from 2010 to 2019 in the form of quarterly. Based on the results of testing the determination of the analysis tool model shows that the right estimation model is Vector Auto Regression (VAR). The results of this study indicate that money supply has a significant relationship to economic growth. While interest rates, exchange rates, and inflation do not have a significant relationship to economic growth
\end{abstract}

Keywords: Economic Growth, Monetary Policy, Data Time Series, Vector Auto Regression (VAR).

\begin{abstract}
Abstrak. Adanya rangkaian kebijakan moneter pemerintah yang masih belum pasti dalam mempengaruhi pertumbuhan ekonomi merupakan fenomena yang menarik untuk diteliti, terutama karena terjadi di era globalisasi dimana lalu lintas moneter sudah sangat pesat, keadaan tersebut menjadi permasalahan utama dalam penelitian ini. Oleh karena itu, penelitian ini bertujuan untuk mengetahui dampak kebijakan moneter terhadap pertumbuhan ekonomi di Indonesia dengan menggunakan metode analisis kuantitatif. Jenis data yang digunakan adalah data sekunder berupa time series yang bersumber dari Badan Pusat Statistik, Bank Indonesia, dan Kementerian Perdagangan dari tahun 2010 hingga 2019 dalam bentuk Triwulanan. Berdasarkan hasil pengujian penentuan model alat analisis menunjukkan bahwa model estimasi yang tepat adalah Vector Auto Regression (VAR). Hasil penelitian ini menunjukkan bahwa uang beredar memiliki hubungan yang signifikan terhadap pertumbuhan ekonomi. Sedangkan suku bunga, nilai tukar, dan inflasi tidak memiliki hubungan yang signifikan terhadap pertumbuhan ekonomi.
\end{abstract}

Kata kunci: Pertumbuhan Ekonomi, Kebijakan Moneter, Data Time Series, Vector Auto Regression (VAR).

\section{Pendahuluan}

Kebijakan moneter adalah kebijakan pemerintah atau otoritas moneter dengan menggunakan peubah jumlah uang beredar (money supply) dan tingkat bunga (interest rates) untuk memengaruhi tingkat permintaan agregat (agregate demand) dan mengurangi ketidakstabilan di dalam perekonomian (Warjiyo, 2006). Untuk melihat pertumbuhan ekonomi yang stabil, pasokan uang harus tumbuh pada tingkat yang tetap, bukan sedang diatur dan diubah oleh otoritas moneter (Sean, 2019). Pertumbuhan ekonomi adalah peningkatan Gross Domestic Product (GDP) atau Gross National Product (GNP) tanpa meninjau apakah peningkatan tersebut lebih besar atau kecil dari tingkat pertumbuhan penduduk serta apakah terjadi perubahan struktur ekonomi (Asnawi, 2018). Dalam era globalisasi saat ini perekonomian negara lain dapat memengaruhi perekonomian dalam negeri, sehingga kebijakan yang ditetapkan oleh pemerintah baik melalui kebijakan fiskal maupun kebijakan moneter juga akan ikut terpengaruh oleh faktor eksternal (Kemenkeu RI, 2018). Salim (2018) menjelaskan bahwa sisi moneter merupakan bagian yang sangat penting dalam sebuah perekonomian, pertumbuhan ekonomi tidak akan bisa dianalisis tanpa melibatkan persoalan moneter.

Berdasarkan data dari BI dan Badan Pusat Statistik (BPS), kenaikan suku bunga BI dapat berpengaruh terhadap pergerakan pertumbuhan ekonomi domestik dan ekonomi domestik berpotensi mengalami perlambatan seiring dengan naiknyasuku bunga. Bank Indonesia menaikkan suku bunga acuan (BI rate) berada di atas $12 \%$, hal ini mengakibatkan perlambatan pertumbuhan ekonomi yangtumbuh hanya 4,59\% pada triwulan I 2006. Selanjutnya pada tahun 2008 suku bunga BI Rate naik di atas 9\%, yang berakibat ekonomi Indonesia kembali melambat (tumbuh sekitar 4 persen) pada triwulan II 2009, kemudian pada tahun 2013 suku bunga BI Rate naik hingga 7,5\% sehingga pertumbuhan kembali mengalami perlambatan hingga di bawah 5\%. Pada tahun 2017 suku bunga BI 7-Day Rate (BI7DR) mengalami penurunan hingga level terendah yaitu sebesar 4,5\%, sehingga pertumbuhan ekonomi dapat tumbuh stabil di level 5\% (Bank Indonesia, Badan Pusat Statistik, 2018). Dari sisi yang lain suku bunga merupakan salah satu variabel dalam perekonomian yang senantiasa diamati secara cermat karena mampu mempengaruhi kehidupan masyarakat dan mempunyai dampak penting terhadap kesehatan perekonomian (Nofitasari, et al., 2019). Suku bunga yang lebih rendah memiliki dampak positif pada efisiensi modal dan investasi yangmengarah ke ekspansi output yang lebih baik tetapi suku bunga rendah yang berkepanjangan dapat membentuk distorsi dalam bentuk gelembung harga aset yang tidak berkelanjutan (Sari dan Baskara, 2018). Jumlah uang beredar merupakan jumlah seluruh uang dalam 
perekonomian (Putri dan Rosyetti, 2017).

Jumlah uang beredar menjadi salah satu instrumen yang digunakan Bank Indonesia untuk memacu kegiatan perekonomian yang berpengaruh terhadap pertumbuhan ekonomi (Tiwa, 2016). Untuk menjaga stabilitas ekonomi dan tingkat pertumbuhan tertentu yang diharapkan, pemerintah melakukan intervensi untuk menjaga nilai mata uang tetap pada tingkat tertentu terhadap mata uang lainnya (Selimi, et al., 2016). Untuk suatu negara yang memiliki ketergantungan impornya tinggi, penurunan kurs dapat menjadikan kekhawatiran mengenai adanya inflasi karena impor yang tinggi dapat mengakibatkan produsen menaikkan harga jual produknya, dan akhirnya berujung pada kenaikan harga barang atau inflasi (Ilmi, 2017). Inflasi yang terjadi seharusnya dapat dikendalikan/dikontrol sehingga tingkat inflasi tersebut dapat memberikan dampak positif terhadap pertumbuhan ekonomi (Lubis, 2014). Dari sisi lain inflasi merupakan salah satu indikator ekonomi makro yang digunakan untuk mengukur stabilitas perekonomian suatu Negara, dengan adanya inflasi maka kenaikan tingkat inflasi menunjukkan adanya suatu pertumbuhan perekonomian, namun dalam jangka panjang tingkat inflasi yang tinggi sangat memberikan dampak buruk pada perekonomian sebab tingginya tingkat inflasi dapat menyebabkan barang domestik relatif lebih mahal dibadingkan harga barang import (Septiatin, et al., 2016).

Ufoeze, et al., (2018) dalam penelitiannya untuk kasus di Nigeria, menunjukkan bahwa tingkat bunga mempunyai pengaruh positif dan tidak signifikan terhadap pertumbuhan ekonomi, sementara jumlah uang beredar berpengaruh positif dan signifikan terhadap pertumbuhan ekonomi, sedangkan nilai tukar berpengaruh negatif dan signifikan terhadap PDB. Penelitian Nwoko, et al., (2016) menunjukan hasil yang berbeda, bahwa jumlah uangberedar tidak memiliki pengaruh yang signifikan, tingkat bunga memiliki pengaruh negatif dan signifikan secara statistik, hal ini menggambarkan masih terdapat ketidak konsistennan hasil penelitian untuk dampak pergerakan jumlah uang yang beredar terhadap pertumbuhan ekonomi. Hidayat, et al., (2014) dalam penelitiannya menghasilkan bahwa variabel suku bunga berpengaruh negatif signifikan terhadap pertumbuhan ekonomi, sementara tingkat inflasi memiliki pengaruh positif signifikan terhadap pertumbuhan ekonomi. Penelitian Etale dan Ayunku (2016) menunjukan hasil yang berbeda untuk kasus diNigeria, bahwa suku bunga berbanding terbalik dengan pertumbuhan ekonomi, tetapi hubungannya secara statistik tidak signifikan, hal ini menggambarkan masih terdapat ketidak konsistennan hasil penelitian untuk dampak pergerakan suku bunga terhadap pertumbuhan ekonomi. Ahmad, et al., (2013) dalam penelitiannya untuk kasus di Pakistan, menunjukan bahwa inflasi dan nilai tukar memiliki pengaruh negatif dan signifikan terhadap pertumbuhan ekonomi. Penelitian Adeniran, et al., (2014) menunjukkan hasil yang berbeda, bahwa nilai tukar memiliki dampak positif tetapi tidak signifikan terhadap pertumbuhan ekonomi, sedangkan suku bunga dan tingkat inflasi memiliki dampak negatif tetapi tidak signifikan terhadap pertumbuhan ekonomi, hal ini menunjukkan masih terdapat ketidak konsistennan hasil penelitian untuk dampak pergerakan nilai tukar terhadap pertumbuhan ekonomi. Penelitian Fakhri (2011) menunjukkan bahwa inflasi memiliki pengaruh positif yang signifikan secara statistik terhadap pertumbuhan PDB. Penelitian Mahzalena dan Juliansyah (2019), menunjukan hasil yang berbeda, bahwa inflasi memiliki dampak positif dan tidak signifikan terhadap pertumbuhan ekonomi, hal ini menunjukkan masih terdapat ketidak konsistennan hasil penelitian untuk dampak pergerakan inflasi terhadap pertumbuhan ekonomi. Beberapa hasil penelitian yang telah dilakukan, menunjukkan serangkaian kebijakan moneter pemerintah yang masih tidak secara pasti mempengaruhi pertumbuhan ekonomi, keadaan tersebut merupakan fenomena yang menarik untuk diteliti, terutama karena hal tersebut terjadi pada era globalisasi dimana lalu lintas moneter sudah menjadi sangat cepat.

\section{Metode}

Jenis data yang digunakan adalah data sekunder dan dokumentasi yang diperoleh dari Badan Pusat Statistik (BPS), website resmi Bank Indonesia (BI), serta Kementerian Perdagangan. Data yang digunakan adalah data time series triwulan daritahun 2010-2019.

1. Definisi Operasional Variabel

a) Pertumbuhan Ekonomi (Y), pertumbuhan ekonomi merupakan indikator keberhasilan pembangunan suatu perekonomian karena kesejahteraan dan kemajuan suatu perekonomian ditentukan oleh besarnya pertumbuhan yang ditunjukan oleh perubahan output nasional (Nugroho, 2014). Data yang digunakan adalah data time series selama 10 tahun dari tahun 2010 hingga 2019 dengan satuan persen.

b) Jumlah uang Beredar (X1), jumlah Uang Beredar (JUB) yang digunakan adalah jumlah uang secara luas yaitu M2 periode 2010 hingga 2019 yang diterbitkan BPS. M2 meliputi M1, uang kuasi, dan surat berharga yang diterbitkan oleh sistem moneter yang dimiliki sektor swasta domestik dengan sisa jangka waktu sampai dengan satu tahun (Utami dan Suryaningsih, 2011). Variabel ini dinyatakan dalam satuan milyar rupiah.

c) Suku Bunga (X2), tingkat suku bunga BI rate merupakan salah satu faktor ekonomi makro yang mempengaruhi harga saham. BI rate merupakan suku bunga kebijakan moneter yang ditetapkan oleh Bank Indonesia (Saridawati, 2015). Data yang digunakan yaitu dari tahun 2010 sampai dengan 2019, Variabel ini dinyatakan 
dalam persen.

d) Nilai Tukar Dollar Amerika (X3), nilai tukar merupakan harga suatu mata uang terhadap mata uang lainnya (Nurrohim, 2013). Nilai tukar Dollar Amerika (Kurs) yang digunakan adalah kurs dengan mata uang rupiah terhadap dollar AS di Kementrian Perdagangan (KEMENDAG) periode 2010 sampai dengan 2019. Variabel ini dinyatakan dengan satuan rupiah per dollar (Rp/US Dolar).

e) Inflasi (X4), inflasi merupakan kenaikan harga-harga secara umum dan terus menerus dan jika kenaikan harga barang terjadi pada satu atau dua jenis barang saja maka tidak bisa dikatakan sebagai inflasi (Ali, et al., 2019).

Data yang digunakan yaitu dari tahun 2010 hingga 2019, variabel ini dinyatakan dalam persen.

Pendekatan yang digunakan untuk menganalisis hubungan dan pengaruh antar variabel berupa pendekatan ekonometrika. Model alat analisis yang digunakan adalah model Vector Auto Regression (VAR), dengan model persamaan VAR sebagai berikut (Abustan, 2018):

$\mathrm{PDB}_{\mathrm{t}}=\beta_{1 \mathrm{i}}+\sum \beta_{1 \mathrm{i}} \mathrm{PDB}-\mathrm{i}+\sum \gamma_{1 \mathrm{i}} \mathrm{JUB}-\mathrm{i}+\sum \delta_{1 \mathrm{i}} \mathrm{SB}-\mathrm{i}+\sum_{1 \mathrm{i}} \mathrm{KURS}_{1 \mathrm{i}}+\sum_{1 \mathrm{i}} \mathrm{INF}_{\mathrm{t}-\mathrm{i}}+\mathrm{e}_{\mathrm{t}}$

$\mathrm{JUB}_{\mathrm{t}}=\beta_{2-\mathrm{i}}+\sum \beta_{2 \mathrm{i}} \mathrm{PDB}-\mathrm{i}+\sum \gamma_{2 \mathrm{i}} \mathrm{JUB}-\mathrm{i}+\sum \delta_{2 \mathrm{i}} \mathrm{SB}-\mathrm{i}+\sum_{2 \mathrm{i}} \mathrm{KURS}_{1 \mathrm{i}}+\sum \sum_{2 \mathrm{i}} \mathrm{INF}_{\mathrm{t}-\mathrm{i}}+\mathrm{e}_{\mathrm{t}}$

$\mathrm{SB}_{\mathrm{t}}=\beta_{3-\mathrm{i}}+\sum \beta_{3 \mathrm{i}} \mathrm{PDB}-\mathrm{i}+\sum \gamma_{3 \mathrm{i}} \mathrm{JUB}-\mathrm{i}+\sum \delta_{3 \mathrm{i}} \mathrm{SB}-\mathrm{i}+\sum_{3 \mathrm{i}} \mathrm{KURS}_{1 \mathrm{i}}+\sum_{3 \mathrm{i}} \mathrm{INF}_{\mathrm{t}-\mathrm{i}}+\mathrm{e}_{\mathrm{t}}$

$\mathrm{KURS}_{\mathrm{t}}=\beta_{4-\mathrm{i}}+\sum \beta_{4 \mathrm{i}} \mathrm{PDB}-\mathrm{i}+\sum \gamma_{4 \mathrm{i}} \mathrm{JUB}-\mathrm{i}+\sum \delta_{4 \mathrm{i}} \mathrm{SB}-\mathrm{i}+\sum{ }_{4 \mathrm{i}} \mathrm{KURS}_{1 \mathrm{i}}+\sum{ }_{4 \mathrm{i}} \mathrm{INF}_{\mathrm{t}-\mathrm{i}}+\mathrm{e}_{\mathrm{t}} \mathrm{INF}_{\mathrm{t}}=\beta_{5-\mathrm{i}}+\sum \beta_{5 \mathrm{i}} \mathrm{PDB}-\mathrm{i}$ $+\sum \gamma_{5 \mathrm{i}} \mathrm{JUB}-\mathrm{i}+\sum \delta_{5 \mathrm{i}} \mathrm{SB}-\mathrm{i}+\sum_{5 \mathrm{i}} \mathrm{KURS}_{1 \mathrm{i}}+\sum_{5 \mathrm{i}} \mathrm{INF}_{\mathrm{t}-\mathrm{i}}+\mathrm{e}_{\mathrm{t}}$

Dimana: $\mathrm{PDB}_{\mathrm{t}}=$ pertumbuhan ekonomi triwulan $\mathrm{t} ; \mathrm{JUBt}=$ jumlah uang beredar triwulan $\mathrm{t} ; \mathrm{SB}_{\mathrm{t}}=$ suku bunga $\mathrm{BI}$ rate triwulan $\mathrm{t}$; KURS $\mathrm{K}_{\mathrm{t}}=$ nilai tukar triwulan $\mathrm{t} ; \mathrm{INF}_{\mathrm{t}}=$ Inflasi triwulan $\mathrm{t} \beta_{1}, \beta_{2}, \beta_{3}, \beta_{4}=$ koefisien regresi $\delta_{1}, \delta_{2}, \delta_{3}, \delta_{4}=$ uji root test $\mathrm{e}_{\mathrm{t}}=$ error term

\section{Hasil}

Tahap pertama yang harus dilalui untuk mendapatkan estimasi VAR adalah pengujian stasioneritas data masing-masing variabel, baik variabel dependen, maupun variabel independen. Persamaan regresi dengan variabelvariabel yang tidak stasioner, dapat menghasilkan regresi lancung atau spurious regression (Sari dan Sulistianingsih, 2019). Dalam penelitian ini, untuk mengetahui stasioner atau tidaknya data suatu variabel, digunakan uji ADF (Augmented Dickey Fuller) dengan menggunakan model intercept, karena dari hasil uji pada tingkat level dan differencing pertama (first difference) ternyata data runtut waktu belum juga stasioner, maka langkah selanjutnya dilakukan ujidifferencing kedua (second differencing). Adapun uji stasioner ADF dengan differencing kedua (second difference) masing-masing variabel dapat ditunjukan pada tabel berikut ini:

Tabel 1.

Hasil Uji Statistik

\begin{tabular}{|c|c|c|c|c|}
\hline Variabel & ADF t-statistik & MC Kinnon Critical Value 5 Persen & Prob & Keterangan \\
\hline $\mathrm{Y}(\mathrm{PDB})$ & -111.1645 & -2.948404 & 0,0001 & Stasioner \\
\hline $\mathrm{X} 1$ (JUB) & -7.147192 & -2.948404 & 0,0000 & Stasioner \\
\hline $\mathrm{X} 2(\mathrm{SB})$ & -6.086302 & -2.943427 & 0,0000 & Stasioner \\
\hline X3 (KURS) & -7.477012 & -2.943427 & 0,0000 & Stasioner \\
\hline X4 (INFLASI) & -7.274541 & -2.948404 & 0.0000 & Stasioner \\
\hline
\end{tabular}

Sumber: data olahan

Tabel 1 diatas dapat diketahui bahwa semua variabel yang digunakan dalam penelitian ini stasioner pada tingkat $2^{\text {nd }}$ difference.

\section{Penentuan Panjang Lag}

Data variabel sudah stasioner pada tingkat $2^{\text {nd }}$ difference maka estimasi dapat menghasilkan keluaran model yang valid. Dengan demikian kesimpulan penelitian mempunyai tingkat validitas yang tinggi pula. Estimasi model VAR dimulai dengan menentukan berapa panjang lag yang tepat dalam model VAR. Jika lag optimal yang dimasukan terlalu pendek maka tidak dapat menjelaskan kedinamisan model secara menyeluruh dan jika lag optimal terlalu panjang maka dapat menghasilkan estimasi yangtidak efisien karena berkurangnya degree of freedom (terutama model dengan sampel kecil). Panjang lag yang diikutsertakan yaitu 0 sampai dengan 10, karena data yang dipakai adalah triwulan yaitu 40 data. Panjang lag optimal dapat ditunjukan pada tabel berikut ini:

Tabel 2.

Hasil Uji Lag Optimum

\begin{tabular}{|c|c|c|c|c|c|c|}
\hline \multirow{2}{*}{\multicolumn{7}{|c|}{ FPE }} \\
\hline & LogL & LR & & AIC & $\mathrm{SC}$ & $\mathrm{HQ}$ \\
\hline 0 & -1716.440 & NA & $2.35 e+35$ & 95.63555 & 95.85548 & 95.71231 \\
\hline 1 & -1683.535 & 54.84068 & $1.54 e+35$ & 95.19641 & 96.51601 & 95.65699 \\
\hline
\end{tabular}


Hari Winarto, Adi Poernomo dan Agus Prabawa, Analisis Dampak Kebijakan Moneter Terhadap Pertumbuhan Ekonomi Di Indonesia

\begin{tabular}{|c|c|c|c|c|c|c|}
\hline 2 & -1627.373 & 78.00307 & $2.97 e+34$ & 93.46518 & 95.88444 & 94.30957 \\
\hline & -1580.877 & $51.66231 *$ & $1.14 \mathrm{e}+34^{*}$ & $92.27095^{*}$ & $95.78988 *$ & $93.49915 *$ \\
\hline
\end{tabular}

Sumber: data olahan

Hasil uji lag optimum pada tabel diatas dapat diketahui bahwa semua tanda bintang berada pada lag 3, yang berarti lag 3 ditetapkan sebagai lag optimum dan digunakan disemua tahap analisis VAR berikutnya. Hasil estimasi menggunakan model VAR dapat menghasilkan fungsi variance decomposition dan fungsi impulse response yang digunakan untuk menjawab permasalahan dalam penelitian ini.

\section{Uji Kointegrasi}

Berdasarkan panjang lag diatas, langkah selanjutnya dilakukan uji kointegrasi untuk mengetahui ada tidaknya pengaruh jangka panjang antar variabel-variabel yang diteliti. Kriteria pengujian kointegrasi ini didasarkan pada nilai trace statistic, apabila nilai trace statistic lebih besar daripada critical value maka terdapat hubungan kointegrasi yang berarti estimasi VAR tidak dapat digunakan, melainkan harus menggunakan model VECM (Vector Error Correction Model). Dalam penelitian ini, pengujian kointegrasi digunakan dengan metode Johansen's Cointegration Test yang tersedia dalam software e-views dengan critical value 0,05. Hasil uji kointegrasi ditunjukan pada tabel berikut ini:

Tabel 3.

Hasil Uji Kointegrasi

\begin{tabular}{|c|c|c|c|c|}
\hline Hypothesized No. of CE(s) & Eigen value & Trace Statistic & 0.05 Critical Value & Prob.** \\
\hline None $*$ & 0.826324 & 107.9897 & 69.81889 & 0.0000 \\
\hline At most 1 & 0.438335 & 41.46831 & 47.85613 & 0.1742 \\
\hline At most 2 & 0.264889 & 19.54802 & 29.79707 & 0.4540 \\
\hline At most 3 & 0.185540 & 7.854124 & 15.49471 & 0.4811 \\
\hline At most 4 & 0.001456 & 0.055373 & 3.841466 & 0.8139 \\
\hline
\end{tabular}

Sumber: data olahan

Berdasarkan tabel 3 dapat dilihat bahwa nilai trace statistic dan maximum eigen value pada $\mathrm{r}=0$ lebih kecil daripada critical value dengan tingkat signifikansi 5 persen. Hal ini berarti hipotesis nol yang menyatakan bahwa tidak ada kointegrasi diterima dan hipotesis alternatif yang menyatakan bahwa ada kointegrasi ditolak. Berdasarkan analisis ekonometrik di atas dapat dilihat bahwa di antara kelima variabel dalam penelitian ini, terdapat satu kointegrasi pada tingkat signifikansi 5 persen. Dengan demikian, dari hasil uji kointegrasi dapat dilihat bahwa di antara pergerakan Pertumbuhan ekonomi, Jumlah Uang Beredar, Suku Bunga, Nilai Tukar dan Inflasi tidak memiliki hubungan dalam jangka panjang.

\section{Uji Kausalitas Granger (Granger's Causality Test)}

Uji kausalitas dilakukan untuk mengetahui apakah suatu variabel endogen dapat diperlakukan sebagai variabel eksogen atau dengan kata lain Uji kausalitas granger dimaksud untuk mengetahui hubungan sebab akibat dari masingmasing variabel independen terhadap variabel dependen. Uji kausalitas dapat dilakukan dengan berbagai metode diantaranya metode Granger's Causality dan Error Correction Model Causality.Pada penelitian ini, digunakan metode Granger's Causality. Taraf uji yang digunakan yaitu 0,05 (5 persen) dan panjang lag sampai pada lag 3 sesuai dengan pengujian panjanglag optimum yang telah dilakukan. Hasil uji kausalitas granger ditunjukan pada tabel berikut ini:

Tabel 4.

Hasil Uji Kausalitas Granger

\begin{tabular}{lrrr}
\hline \multicolumn{1}{c}{ Null Hypothesis: } & Obs & F-Statistic & Prob \\
\hline JUB does not Granger Cause PDB & 37 & 2.36081 & 0.0042 \\
PDB does not Granger Cause JUB & & 5.16351 & 0.0925 \\
SB does not Granger Cause PDB & 37 & 0.27086 & 0.8459 \\
PDB does not Granger Cause SB & & 1.06901 & 0.3770 \\
KURS does not Granger Cause PDB & 37 & 0.20640 & 0.8912 \\
PDB does not Granger Cause KURS & & 1.48436 & 0.2387 \\
INFLASI does not Granger Cause PDB & 37 & 0.81529 & 0.4956 \\
PDB does not Granger Cause INFLASI & & 0.30205 & 0.8236 \\
\hline
\end{tabular}

Sumber: data olahan

Tabel 4 dapat dilihat bahwa variabel JUB secara statistik signifikan mempengaruhi PDB, tetapi sebaliknya PDB secara statistik tidak signifikan mempengaruhi JUB. Keadaan ini dibuktikan dengan nilai probabilitias JUB lebih 
kecil dari 0,05 yaitu 0.0042 yang artinya hipotesis nol ditolak dan nilai probabilitas PDB lebih besar dari 0,05 yaitu 0.0925 yang artinya hipotesis nol diterima. Sehingga dapat disimpulkan bahwa terjadi kausalitas searah yaitu variabel JUB yang secara statistik signifikan mempengaruhi PDB dan tidak berlaku sebaliknya. Tabel 4 dapat dilihat bahwa variabel SB secara statistik tidak signifikan mempengaruhi PDB, begitu juga sebaliknya PDB secara statistik tidak signifikan mempengaruhi SB. Keadaan ini dibuktikan dengan nilai probabilitas masing-masing lebih besar dari 0,05 yaitu 0.8459 dan 0.3770 yang artinya hipotesis nol diterima oleh keduanya. Sehingga dapat disimpulkan bahwa tidak terjadi kausalitas apapun untuk kedua variabel SB dan PDB. Tabel diatas dapat dilihat bahwa variabel KURS secara statistik tidak signifikan mempengaruhi PDB, begitu juga sebaliknya PDB secara statistik tidak signifikan mempengaruhi KURS. Keadaan ini dibuktikan dengan nilai probabilitas masing-masing lebih besar dari 0,05 yaitu 0.8912 dan 0.2387 yang artinya hipotesis nol diterima oleh keduanya. Sehingga dapat disimpulkan bahwa tidak terjadi kausalitas apapun untuk kedua variabel KURS dan PDB. Tabel diatas dapat dilihat bahwa variabel INFLASI secara statistik tidak signifikan mempengaruhi PDB, begitu juga sebaliknya PDB secara statistik tidak signifikan mempengaruhi inflasi. Keadaan ini dibuktikan dengan nilai probabilitas masing-masing lebih besar dari 0,05 yaitu 0.4956 dan 0.8236 yang artinya hipotesis nol diterima oleh keduanya. Sehingga dapat disimpulkan bahwa tidak terjadi kausalitas apapun untuk kedua variabel INFLASI dan PDB.

\section{Analisis Impulse Response Function (IRF)}

Analisis IRF yaitu menjelaskan dampak dari guncangan (shock) pada suatu variabel terhadap variabel lain, dimana dalam analisis ini tidak hanya dalam waktu pendek tetapidapat menganalisis untuk beberapa horizon kedepan sebagai informasi jangka panjang. Analisis impulse response function juga berfungsi untuk melihat berapa lama pengaruh tersebut terjadi. Sumbu horizontal merupakan periode dalam tahun, sedangkan sumbu vertikal menunjukan nilai respon dalam persentase.
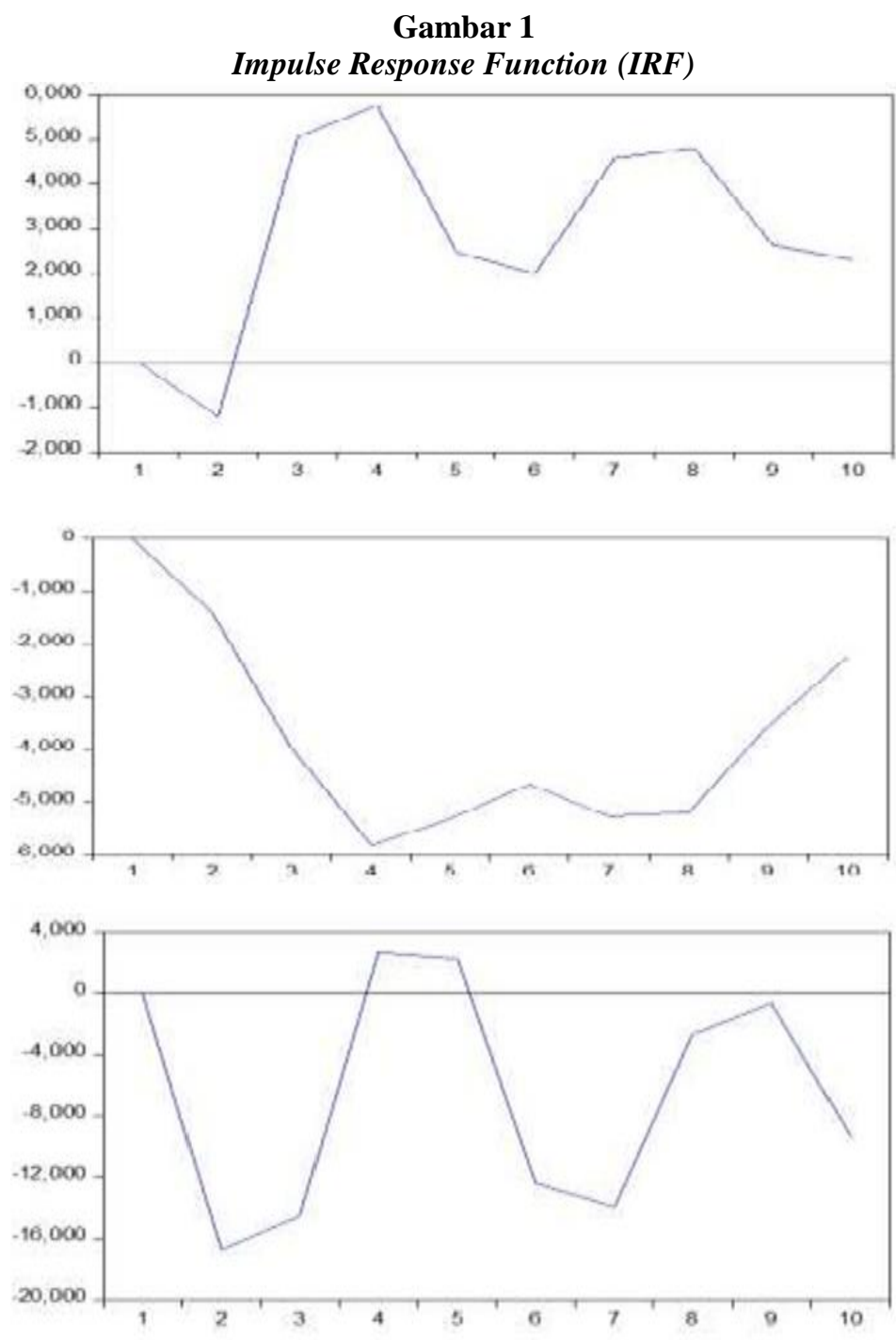

Sumber: data olahan 
Gambar 1 diatas dapat diketahui bahwa respon variabel PDB terhadap shock yang ditimbulkan oleh Jumlah Uang Beredar (JUB) pada periode kedua mengalami respon negatif terbukti dari garis IRF berada dibawah garis horizontal, pada periode ketiga hingga sepuluh menunjukan shock yang berfluktuatif dan mengalami respon positifyang terbukti dari garis IRF berada diatas garis horizontal. Gambar 1 dapat diketahui bahwa respon variabel PDB terhadap shock yang ditimbulkan oleh Suku Bunga (SB) menunjukan respon negatif yang dapat dilihat dari periode satu hingga sepuluh yang terbukti dari garis IRF berada di bawah garis horizontal. Gambar 1 dapat diketahui bahwa respon variabel PDB terhadap shock yang ditimbulkan oleh Nilai Tukar (KURS) menunjukan respon negatif pada periode satu hingga tiga yang terbukti dari garis IRF berada di bawah garis horizontal, selanjutnya pada periode ke empat dan lima menunjukan respon positif yang terbukti dari garis IRF berada di atas garis horizontal, kemudian pada periode ke enam hingga sepuluh kembalimenunjukan respon negatif yang terbukti dari garis IRF berada di bawah garis horizontal. Gambar 1 di atas dapat diketahui bahwa respon variabel PDB terhadap shock yang ditimbulkan oleh Inflasi menunjukan respon positif yang dapat dilihat dari periode satu hingga sepuluh yang terbukti dari garis vertikal menunjukan nilai positif.

\section{Dekomposisi Varian (Variance Decomposition)}

Analisis VD dari variabel Y (PDB) pada tabel diatas menunjukan bahwa variabel yang memiliki kontribusi paling besar terhadap PDB sepuluh tahun kedepan yaitu PDB itu sendiri dengan rata-rata kontribusi per tahun sebesar 69,03 persen, selanjutnya diikutioleh kontribusi X3 (Kurs) sebesar 23,03 persen, X2 (SB) sebesar 3,11 persen, X1 (JUB)sebesar 2,47 persen dan X4 (Inflasi) sebesar 2,37 persen. Analisis VD dari variabel X1 (JUB) pada tabel diatas menunjukan bahwa variabel yang memiliki kontribusi paling besar terhadap Jumlah Uang Beredar sepuluh tahun kedepan yaitu Jumlah Uang Beredar itu sendiri dengan rata-rata kontribusi per tahun sebesar 64,98 persen, selanjutnya diikuti oleh kontibusi X3 (Kurs) sebesar 17,30 persen,Y (PDB) sebesar 7,97 persen, X4 (Inflasi) sebesar 5 persen dan X2 (SB) sebesar 4,75 persen. Selama lima tahun pertama, kontribusi X2 (SB) bertambah, kontribusi X3 (Kurs)dan X4 (Inflasi) juga bertambah dari tahun pertama hingga kesepuluh, berbeda dengan kontribusi Y (PDB) yang tidak menentu karena pada dua tahun pertama mengalami kenaikan namun pada tahun ketiga dan keempat mengalami penurunan kontribusi.

Tabel 5.

Hasil Uji Variance Decomposition

\begin{tabular}{lrrrrr}
\hline Period & S.E. & PDB & JUB & SB & Kurs \\
\hline 1 & 29027.91 & 100.0000 & 0.000000 & 0.000000 & 0.000000 \\
2 & 37552.27 & 79.75295 & 0.103025 & 0.137889 & 19.88066 \\
3 & 42920.36 & 69.08509 & 1.471999 & 0.970236 & 26.67409 \\
4 & 44549.40 & 65.91195 & 3.046184 & 2.606678 & 25.12984 \\
5 & 47985.55 & 68.78728 & 2.893451 & 3.476897 & 21.88226 \\
6 & 51499.07 & 66.15869 & 2.662800 & 3.839933 & 24.76721 \\
7 & 54133.36 & 60.67000 & 3.127388 & 4.425936 & 29.04522 \\
8 & 54939.48 & 59.13239 & 3.808618 & 5.193421 & 28.43064 \\
9 & 56505.83 & 60.53996 & 3.817361 & 5.305933 & 26.88828 \\
10 & 58455.21 & 60.24865 & 3.721840 & 5.104234 & 27.64700 \\
\hline
\end{tabular}

Sumber: data olahan

Tabel 6.

Hasil Analisis Variance Decomposition (VD) variabel X1

\begin{tabular}{|c|c|c|c|c|c|}
\hline Period & S.E. & PDB & JUB & SB & Kurs \\
\hline 1 & 110432.0 & 2.542871 & 97.45713 & 0.000000 & 0.000000 \\
\hline 2 & 134120.7 & 5.053796 & 90.22395 & 3.701483 & 0.325563 \\
\hline 3 & 163223.2 & 3.887044 & 78.65259 & 6.318446 & 8.422595 \\
\hline 4 & 185541.9 & 3.009276 & 72.29184 & 7.130873 & 13.79621 \\
\hline 5 & 204291.3 & 4.680894 & 66.84012 & 7.016427 & 16.28900 \\
\hline 6 & 225914.5 & 10.01943 & 58.49400 & 6.023016 & 19.70757 \\
\hline 7 & 247537.2 & 11.72865 & 51.63872 & 5.076046 & 25.10572 \\
\hline 8 & 264754.2 & 11.55489 & 47.76877 & 4.470187 & 28.59943 \\
\hline 9 & 279698.9 & 12.50301 & 44.93828 & 4.054293 & 29.82919 \\
\hline 10 & 296661.2 & 14.71842 & 41.52764 & 3.695696 & 30.91829 \\
\hline
\end{tabular}

Sumber: data olahan 
Hari Winarto, Adi Poernomo dan Agus Prabawa, Analisis Dampak Kebijakan Moneter Terhadap Pertumbuhan Ekonomi Di Indonesia

Tabel 7.

Hasil Analisis Variance Decomposition (VD) variabel X2

\begin{tabular}{|c|c|c|c|c|c|}
\hline Period & S.E. & PDB & JUB & SB & Kurs \\
\hline 1 & 0.918055 & 0.251501 & 0.754592 & 98.99391 & 0.000000 \\
\hline 2 & 1.696714 & 0.596238 & 0.271297 & 97.49619 & 1.636101 \\
\hline 3 & 2.327337 & 2.647389 & 0.345138 & 93.00878 & 3.730781 \\
\hline 4 & 2.775249 & 4.410761 & 0.436617 & 88.97052 & 5.853343 \\
\hline 5 & 3.017020 & 5.083033 & 0.489413 & 87.25842 & 6.827786 \\
\hline 6 & 3.111074 & 5.274544 & 0.472574 & 87.06406 & 6.845417 \\
\hline 7 & 3.135760 & 5.294411 & 0.484975 & 87.12150 & 6.738067 \\
\hline 8 & 3.143873 & 5.286186 & 0.635724 & 86.83143 & 6.859907 \\
\hline 9 & 3.161661 & 5.567683 & 0.965114 & 85.87416 & 7.186069 \\
\hline 10 & 3.190721 & 6.032635 & 1.377567 & 84.51441 & 7.657282 \\
\hline
\end{tabular}

Sumber: data olahan

Analisis VD dari variabel X2 (SB) pada tabel di atas menunjukan bahwa variabel yang memiliki kontribusi paling besar terhadap Suku Bunga sepuluh tahun kedepan yaituSuku Bunga itu sendiri dengan rata-rata kontribusi per tahun sebesar 89,71 persen, selanjutnya diikuti oleh kontibusi X3 (Kurs) sebesar 5,33 persen, Y (PDB) sebesar 4,04 persen, X1 (JUB) sebesar 0,62 persen dan X4 (Inflasi) sebesar 0,29 persen.

Tabel 8

Hasil Analisis Variance Decomposition (VD) variabel X3

\begin{tabular}{|c|c|c|c|c|c|}
\hline Period & S.E. & PDB & JUB & SB & Kurs \\
\hline 1 & 936.1413 & 10.64583 & 15.68736 & 22.53556 & 51.13124 \\
\hline 2 & 1485.357 & 11.16998 & 15.95731 & 25.03230 & 47.62049 \\
\hline 3 & 1896.123 & 18.70356 & 17.92827 & 24.72707 & 38.31298 \\
\hline 4 & 2200.456 & 24.54146 & 18.73544 & 23.32321 & 33.10220 \\
\hline 5 & 2338.195 & 24.53311 & 19.31494 & 23.80190 & 32.07225 \\
\hline 6 & 2386.233 & 23.64540 & 19.53260 & 25.36903 & 31.17787 \\
\hline 7 & 2417.851 & 23.07636 & 19.40164 & 26.75415 & 30.48940 \\
\hline 8 & 2444.336 & 22.71949 & 19.15195 & 27.68678 & 30.04577 \\
\hline 9 & 2460.918 & 22.44212 & 18.93650 & 28.35325 & 29.69781 \\
\hline 10 & 2478.849 & 22.62935 & 18.66462 & 28.56355 & 29.45271 \\
\hline
\end{tabular}

Sumber: data olahan

Analisis VD dari variabel X3 (Kurs) pada tabel di atas menunjukan bahwa variabelyang memiliki kontribusi paling besar terhadap Nilai Tukar Rp/U\$ sepuluh tahun kedepan yaitu Nilai Tukar Rp/U\$ itu sendiri dengan rata-rata kontribusi per tahun sebesar35,31 persen, selanjutnya diikuti oleh kontibusi X2 (SB) sebesar 25,61 persen, Y (PDB) sebesar 20,41 persen, X1 (JUB) sebesar 18,33 persen dan X4 (Inflasi) sebesar 0,33 persen.

Tabel 9

Hasil Analisis Variance Decomposition (VD) variabel X4

\begin{tabular}{|c|c|c|c|c|c|}
\hline Period & S.E. & PDB & JUB & SB & Kurs \\
\hline 1 & 50782.39 & 2.151637 & 6.845464 & 4.363553 & 0.454861 \\
\hline 2 & 54617.19 & 3.327788 & 6.097975 & 10.77382 & 4.410485 \\
\hline 3 & 55603.28 & 3.212763 & 6.458784 & 13.09489 & 4.478822 \\
\hline 4 & 55866.41 & 3.186033 & 6.445218 & 13.70963 & 4.561212 \\
\hline 5 & 56080.84 & 3.392270 & 6.399567 & 13.67134 & 4.880609 \\
\hline 6 & 56120.85 & 3.403409 & 6.474845 & 13.65204 & 4.884230 \\
\hline 7 & 56461.61 & 4.276820 & 6.560998 & 13.52074 & 4.908706 \\
\hline 8 & 56809.41 & 4.667394 & 6.646484 & 13.43502 & 5.380779 \\
\hline 9 & 56984.20 & 4.638844 & 6.669005 & 13.51310 & 5.717152 \\
\hline 10 & 57066.93 & 4.641280 & 6.690024 & 13.67819 & 5.713993 \\
\hline
\end{tabular}

Sumber: data olahan

Analisis VD dari variabel X4 (Inflasi) pada tabel di atas menunjukan bahwa variabel yang memiliki kontribusi paling besar terhadap Inflasi sepuluh tahun kedepan yaitu Inflasi itu sendiri dengan rata-rata kontribusi per tahun sebesar 72,90 persen, selanjutnya diikuti oleh kontibusi X2 (SB) sebesar 12,34 persen, X1 (JUB) sebesar 6,53 persen, X3 (Kurs) sebesar 4,54 persen dan Y (PDB) sebesar 3,69 persen. 


\section{Simpulan}

1. Jumlah Uang Beredar berpengaruh signifikan terhadap Pertumbuhan Ekonomi di Indonesia, yang dibuktikan dengan nilai probabilitias Jumlah Uang Beredar lebih kecil dari 0,05 yaitu 0.0042 yang artinya hipotesis nol ditolak dan dari hasil uji kointegrasi dapat dilihat bahwa Jumlah uang beredar tidak memiliki hubungan dalam jangka panjangterhadap Pertumbuhan Ekonomi

2. Suku Bunga berpengaruh tidak signifikan terhadap Pertumbuhan Ekonomi di Indonesia, yang dibuktikan dengan nilai probabilitas Suku Bunga lebih besar dari 0,05 yaitu 0.8459yang artinya hipotesis nol diterima dan dari hasil uji kointegrasi dapat dilihat bahwa SukuBunga tidak memiliki hubungan dalam jangka panjang terhadap Pertumbuhan Ekonomi

3. Nilai Tukar berpengaruh tidak signifikan terhadap Pertumbuhan Ekonomi di Indonesia, yang dibuktikan dengan nilai probabilitas Nilai Tukar lebih besar dari 0,05 yaitu 0.8912 yang artinya hipotesis nol diterima dan dari hasil uji kointegrasi dapat dilihat bahwa NilaiTukar tidak memiliki hubungan dalam jangka panjang terhadap Pertumbuhan Ekonomi

4. Inflasi berpengaruh tidak signifikan terhadap Pertumbuhan Ekonomi di Indonesia, yang dibuktikan dengan nilai probabilitas Inflasi lebih besar dari 0,05 yaitu 0.4956 yang artinyahipotesis nol diterima dan dari hasil uji kointegrasi dapat dilihat bahwa Inflasi tidak memiliki hubungan dalam jangka panjang terhadap Pertumbuhan Ekonomi.

\section{Implikasi}

1. Pemerintah perlu meningkatkan jumlah uang beredar dengan cara melakukan kebijakan moneter ekspansif, sehingga dapat mengatasi pengangguran dan meningkatkan daya beli masyarakat pada saat perekonomian mengalami depresi, sebab peningkatan jumlah uang beredar mengindikasikan adanya kesejahteraan di masyarakat dan dengan kesejahteraan yang meningkat maka tabungan dan investasi juga dapat meningkat sehingga dapat meningkatkan pertumbuhan ekonomi. Namun pemerintah juga perlu memperhatikan dampak negatif dari meningkatnya jumlah uang beredar yaitu terjadinya inflasi.

2. Bank Indonesia perlu menstabilkan laju inflasi agar tetap rendah dengan menggunakan salah satu dari kebijakan moneter seperti kebijakan diskonto yaitu dengan meningkatkan nilai suku bunga BI rate supaya masyarakat terdorong untuk menabung sehingga jumlahuang yang beredar dapat berkurang dan laju inflasi bisa ditekan.

3. Dengan mempertimbangkan besarnya tekanan depresiasi rupiah yang dapat mengganggukestabilan makro ekonomi, maka Bank Indonesia selaku otoritas moneter perlu melakukan beberapa langkah kebijakan moneter terkait dengan upaya stabilisasi nilai tukar, seperti peningkatan Bi Rate maupun pengoptimalan instrumen moneter kontraksi,yaitu peningkatan GWM (Giro Wajib Minimun) yang dapat membawa dampak positif terhadap nilai tukar, seperti berkurangnya jual beli valuta asing oleh masyarakat dan memperbaiki daya saing perbankan domestik terutama dalam upaya menarik devisa hasilekspor yang dapat menambah pasokan valuta asing sehingga dapat mendorong apresiasi rupiah.

\section{Daftar Pustaka}

Ahmad, A., Ahmad, N., \& Ali, S. (2013). Exchange rate and economic growth in Pakistan (1975-2011). Ahmad, Arslan, Najid Ahmad, and Sharafat Ali." Exchange Rate and Economic Growth in Pakistan (19752011)."(2013), 740-746.

Ali, K., Sari, D. R., \& Putri, R. (2019). Pengaruh Inflasi Nilai Tukar Rupiah Dan Harga Emas Dunia Terhadap Indeks Harga Saham Pertambangan PadaBursa Efek Indonesia (Periode Tahun 2016-2018). Jurnal Bisnis Darmajaya, 5(2), 90-113.

Adeniran, J. O., Yusuf, S. A., \& Adeyemi, O. A. (2014). The impact of exchange rate fluctuation on the Nigerian economic growth: An empirical investigation. International journal of Academic Research in Business and Social sciences, 4(8): 224.

Asnawi, A., \& Fitria, H. (2018). PENGARUH JUMLAH UANG BEREDAR, TINGKAT SUKU BUNGA DAN INFLASI TERHADAP PERTUMBUHAN EKONOMI DI INDONESIA. Ekonomika Indonesia, 7(01), 24-32.

Etale, L. M., \& Ayunku, P. E. (2016). The relationship between interest rate and economic growth in Nigeria: An Error Correction Model (ECM) approach. International Journal of Economics and Financial Research, 2(6), 127-131.

Fakhri, H. (2011). Relationship between inflation and economic growth in Azerbaijani economy: is there any threshold effect?. Asian Journal of Business and Management Sciences, 1(1), 1-11.

Hidayat, A. S., Suman, A., \& Kaluge, D. (2014). The Effect of Interest Rate, Inflation and Government Expenditure on Economic Growth in Indonesia Period of 2005-2012. Journal of Economics and Sustainable Development, 5(15), 243-9.

Ilmi, M. F. (2017). Pengaruh Kurs/Nilai Tukar Rupiah, Inflasi dan Tingkat Suku Bunga SBI Terhadap Indeks Harga 
Saham Gabungan LQ-45 Periode Tahun 2009-2013. Nominal: Barometer Riset Akuntansi dan Manajemen, 6(1), 93-108.

Kemenkeu RI. (2018). https://www.kemenkeu.go.id/. Diambil Kembali Dari Kemenkeu: https://www.kemenkeu.go.id/Publikasi/Artikel-Dan- Opini/Kebijakan-Fiskal-Kaitannya-Dengan-PertumbuhanEkonomi-Indonesia/

Lubis, I. F. (2014). Analisis Hubungan Antara Inflasi dan Pertumbuhan Ekonomi: Kasus Indonesia. Quantitative Economics Journal, 3(1).

Mahzalena, Y., \& Juliansyah, H. (2019). Pengaruh inflasi, pengeluaran pemerintah dan ekspor terhadap pertumbuhan ekonomi di Indonesia. Jurnal Ekonomi Regional Unimal, 2(1): 37-50.

Nofitasari, R., Amir, A., \& Mustika, C. (2017). Pengaruh inflasi, suku bunga, investasi terhadap pertumbuhan ekonomi Provinsi Jambi. e-Jurnal Perspektif Ekonomi dan Pembangunan Daerah, 6(2), 77-84.

Nugroho, B. S. (2014). Pertumbuhan ekonomi dan ketimpangan pendapatan antar kecamatan. JEJAK: Jurnal Ekonomi dan Kebijakan, 7(1), 46-59.

Nurrohim, M. (2013). Analisis Kausalitas Volatilitas Nilai Tukar Mata Uang Dengan Kinerja Sektor Keuangan Dan Sektor Rill. Economics Development Analysis Journal, 2(4).

Nwoko, N. M., Ihemeje, J. C., \& Anumadu, E. (2016). The impact of monetary policy on the economic growth of Nigeria. African Research Review, 10(3): 192-206.

Putri, V. K., \& Rosyetti, R. (2017). Analisis Pengaruh Jumlah Uang Beredar, Suku Bunga Sertifikat Bank Indonesia dan Suku Bunga Kredit Investasi terhadap Inflasi di Indonesia (Doctoral dissertation, Riau University).

Salim, J. F. (2018). Pengaruh Kebijakan Moneter terhadap Pertumbuhan Ekonomi di Indonesia. Jurnal Ekombis, 3(2).

Sari, G. A. A. R. M., \& Baskara, I. G. K. (2018). Pengaruh Pertumbuhan Ekonomi, Suku Bunga, dan Nilai Tukar terhadap Investasi Asing Langsung di Indonesia (Doctoral dissertation, Udayana University).

Sari, M., \& Sulistianingsih, E. (2019). Model Koreksi Kesalahan (ECM) pada Kasus Data Runtun Waktu Indeks Harga Konsumen di Jawa Tengah. Bimaster, 8(1).

Saridawati, S. (2015). Analisis Peran Kebijakan Moneter Bank Indonesia (BI) Rate terhadap Nilai Tukar US Dolar dan Inflasi. Moneter-Jurnal Akuntansi Dan Keuangan, 2(2).

Sean, M. (2019). The Impact of Monetary Policy on Economic Growth in Cambodia: Bayesian Approach. Journal of Management, Economics, and Industrial Organization, 16-34.

Selimi, N., Reçi, K., \& Sadiku, L. (2016). The Impact of Foreign Direct Investment on the Export Performance: Empirical Evidence for Western Balkan Countries. ILIRIA International Review, 6(1).

Septiatin, A. A., Mawardi, M. M., \& Rizki, M. A. K. (2016). Pengaruh Inflasi dan Tingkat Pengangguran Terhadap Pertumbuhan Ekonomi Di Indonesia. I-Economics: A Research Journal On Islamic Economics, 2(1), $50-65$.

Tiwa, F. R. (2016). Pengaruh Investasi, Suku Bunga Sertifikat Bank Indonesia (Sbi) Dan Jumlah Uang Beredar Terhadap Pertumbuhan Ekonomi Indonesia Tahun 2005-2014. Jurnal Berkala Ilmiah Efisiensi, 16(2).

Ufoeze, L. O., Odimgbe, S. O., Ezeabalisi, V. N., \& Alajekwu, U. B. (2018). Effect of monetary policy on economic growth in Nigeria: An empirical investigation. Annals of Spiru Haret University, Economic Series, 9(1), 123140.

Utami, S. R., \& Suryaningsih, R. (2011). Analisis Pengaruh Narrow Money (M1) Dan Broad Money (M2) Terhadap Laju Inflasi Di Indonesia. Ultimaccounting: Jurnal Ilmu Akuntansi, 3(1), 33-45.

Warjiyo, P. (2006). Stabilitas sistem perbankan dan kebijakan moneter: keterkaitan dan perkembangannya di Indonesia. Buletin Ekonomi Moneter dan Perbankan, 8(4): 429-454. 